\title{
PELATIHAN “ ANDRAGOGICAL CONTENT KNOWLEDGE” BAGI TUTOR KESETARAAN PAKET C DALAM MENINGKATKAN KOMPETENSI PERSONAL PROSES PEMBELAJARAN PADA PESERTA DIDIK DI PUSAT KEGIATAN BELAJAR MASYARAKAT (PKBM) GEMA KELURAHAN CIKALANG KECAMATAN TAWANG KOTA TASIKMALAYA
}

\author{
H. Adang Danial ${ }^{1}, \mathrm{H}$. Syaefuddin ${ }^{2}$, Lulu Yuliani ${ }^{3}$ \\ 1,2,3Jurusan Pendidikan Masyarakat Fakultas Keguruan dan Ilmu Pendidikan \\ Universitas Siliwangi \\ 1adangdanial@unsil.ac.id
}

\begin{abstract}
ABSTRAK
Tujuan umum dalam rencana pelaksanaan pengabdian pada masyarakat ini adalah meningkatkan mutu tutor paket kesetaraan $\mathrm{C}$ dalam proses pembelajaran pada peserta didik di PKBM Gema Kecamatan Tawang Kota Tasikmalaya melalui Pelatihan Tutor paket Kesetaran C berbasis Andragogi ("Andragogical Content Knowledge"). Berdasarkan penemuan dilapangan dan hasil wawancara dengan tutor kesetaraan paket $\mathrm{C}$ di kelurahan Cikalang kecamatan Tawang Kota Tasikmalaya pada umumnya mengharapkan pelatihan selama tiga bulan dalam penerapan metode "Andragogical content knowledge Pembelajaran (Pengetahuan) yang berlandaskan konsep andragogi ("Andragogical Content Knowledge") sangat penting memberi peluang munculnya potensi-potensi yang ada dalam diri peserta belajar. Keterlibatan fisik, mental, dan emosi memunculkan rasa ikhlas dalam memperoleh pengetahuan, menyerap informasi secara efektip dan efisien. Maka metode yang tepat dalam kegiatan ini adalah pelatihan mengenai konsep "Andragogical content knowledge"(pengetahuan/pembelajaran berbasis andragogi) yang akan dilakukan oleh Tutor Paket Kesetaraan serta praktik penerapan pada pembelajaran.
\end{abstract}

Kata Kunci: Pelatihan"Andragogical Content Knowledge", Tutor Kesetaraan Paket C

\section{ABSTRACT}

The general objective in the implementation plan of community service is to improve the quality of the equivalence package $C$ tutor in the learning process in the learner in PKBM Gema Kecamatan Tawang Kota Tasikmalaya through Training of Andragogi C Andragogi ("Andragogical Content Knowledge"). Based on the findings of the field and the results of interviews with the $\mathrm{C}$ package parity equivalent in Cikalang subdistrict, Tawang subdistrict, Tasikmalaya City generally expect three months training in the application of "Andragogical Content Knowledge" method of knowledge and knowledge (Knowledge) opportunities for potential potential in participants. Physical, mental, and emotional involvement creates a sense of sincerity in gaining knowledge, absorbing information effectively and efficiently. Then the appropriate method in this activity is training on the concept of "Andragogical content knowledge" (knowledge / learning based on andragogy) which will be done by the Equivalence Package Tutor and the implementation practice on learning.

Keywords: "Andragogical Content Knowledge" Training, Package Equivalent Tutor C

\section{A. PENDAHULUAN}

PKBM merupakan suatu lembaga pendidikan non formal yang menyelenggarakan program-program Pendidikan Luar Sekolah. Karakteristik penting 
yang dimiliki PKBM adalah adanya partisipasi masyarakat yang terlibat dalam tahapan pengambilan keputusan. Pusat Kegiatan Belajar Masyarakat (PKBM) Gema Kelurahan Kahuripan Kecamatan Tawang adalah salah satu lembaga yang menyelenggarakan Pendidikan Kesetaraan Paket C.

Alasan perlunya Andragogi karena proses belajar orang dewasa berbeda dengan anak sehinggga memerlukan perlakuan yang berbeda pula. Orang dewasa belajar di pandang sebagai transformasi, yaitu mengubah (modifying), mempelajari kembali(relearning), memperbarui (updating), dan mengganti (replacing)." Orientasi belajar orang dewasa terpusat pada kehidupan, sehingga unit pembelajarannya adalah situasi kehidupan, bukan sekedar subyek atau materi pembelajaran. Oleh karena itu dalam pencapaian tujuan sesuai dengan prinsip PKBM maka perlu diterapkan metode pembelajaran berbasis Andragogi (Andragogical Content Knowledge").

Menurut knowles (1980) dalam Marzuki Saleh (2012, hlm. 166) definisi Andragogi adalah seni dan ilmu orang mengajar dewasa. Sebagai ilmu, tidak ubahnya seperti ilmu lain, tentunya andragogi dapat dipelajari oleh siapa saja karena ia mengikuti hukum-hukum keilmuan pada umumnya bersifat objektif. Sebagai seni atau kiat, andragogi adalah aktivitas yang merupakan hasil dari kecakapan kreatif dan kelihaian seseorang yang terkait dengan rasa estetika, terikat dengan kepribadian, karakter atau watak si pendidik.

Metode pembelajaran (Pengetahuan) "Andragogical Content Knowledge" adalah proses pembelajaran dimana tutor dan penyelenggara pendidikannya menerapkan prinsip-prinsip belajar orang dewasa. Dari perspektif waktu dan orientasi belajar, orang dewasa memandang belajar itu sebagai suatu proses pemahaman dan penemuan masalah serta pemecahan masalah (problem finding and problem solving), baik berhubungan dengan masalah kekinian maupun masalah kehidupan di masa depan. Orang dewasa lebih mengacu pada tugas atau masalah kehidupan (task or problem oriented).

Pembelajaran (Pengetahuan) yang berlandaskan konsep andragogi ("Andragogical Content Knowledge") sangat penting memberi peluang munculnya potensi-potensi yang ada dalam diri peserta belajar. Keterlibatan fisik, mental, dan emosi memunculkan rasa ikhlas dalam memperoleh pengetahuan, menyerap informasi secara efektip dan efisien.

Penerapan pembelajaran berbasis Andragogi di nilai sangat penting karena hal 
ini berdampak pada kualitas pembelajaran di paket kesetaraan C. Berdasarkan ontology khususnya dikecamatan Tawang Tutor Paket Kesetaraan C kurang memahami pembelajaran/pengetahuan berbasis Andragogi ("Andragogical Content Knowledge"). Selain itu Tutor Paket Kesetaraan C belum sepenuhnya dapat melaksanakan proses pembelajaran pada peserta didik sebagaimana yang diharapkan.

\section{B. LANDASAN TEORI}

PKBM merupakan suatu lembaga pendidikan non formal yang menyelenggarakan program-program Pendidikan Luar Sekolah. Karakteristik penting yang dimiliki PKBM adalah adanya partisipasi masyarakat yang terlibat dalam tahapan pengambilan keputusan. Pusat Kegiatan Belajar Masyarakat (PKBM) Gema Kelurahan Kahuripan Kecamatan Tawang adalah salah satu lembaga yang menyelenggarakan Pendidikan Kesetaraan Paket C. Pendidikan kesetaraan merupakan salah satu program pendidikan non-formal yang terstruktur dan dinilai. Salah satu program pendidikan kesetaraan adalah Kejar Program Paket C yang setara dengan Sekolah Menengah Atas dalam pendidikan formal dan bertujuan untuk memperluas akses pendidikan tinggi. Kriteria Kejar Paket C peserta didik adalah mereka yang : (1) Telah lulus dari Kejar Paket B Program atau SMP / MTs, (2) Tidak dapat melanjutkan atau menyelesaikan studinya di SMA / MA / SMK / MAK, (3) Tidak ingin belajar di pendidikan formal karena pilihan mereka sendiri, dan (4) Tidak bisa mendapatkan pendidikan di sekolah karena beberapa faktor (potensi, keterbatasan waktu, ekonomi, sosial dan hukum, dan keyakinan).

Andragogi adalah seni dan ilmu orang mengajar dewasa. Sebagai ilmu, tidak ubahnya seperti ilmu lain, tentunya andragogi dapat dipelajari oleh siapa saja karena ia mengikuti hukum-hukum keilmuan pada umumnya bersifat objektif. Sebagai seni atau kiat, andragogi adalah aktivitas yang merupakan hasil dari kecakapan kreatif dan kelihaian seseorang yang terkait dengan rasa estetika, terikat dengan kepribadian, karakter atau watak si pendidik knowles (1980) dalam Marzuki Saleh (2012, hlm. 166). Metode pembelajaran (Pengetahuan) "Andragogical Content Knowledge" adalah proses pembelajaran dimana tutor dan penyelenggara pendidikannya menerapkan prinsipprinsip belajar orang dewasa. Dari perspektif waktu dan orientasi belajar, orang dewasa memandang belajar itu sebagai suatu proses pemahaman dan penemuan masalah serta pemecahan masalah (problem finding and problem solving), baik 
berhubungan dengan masalah kekinian maupun masalah kehidupan di masa depan. Orang dewasa lebih mengacu pada tugas atau masalah kehidupan (task or problem oriented).

\section{METODE PELAKSANAAN}

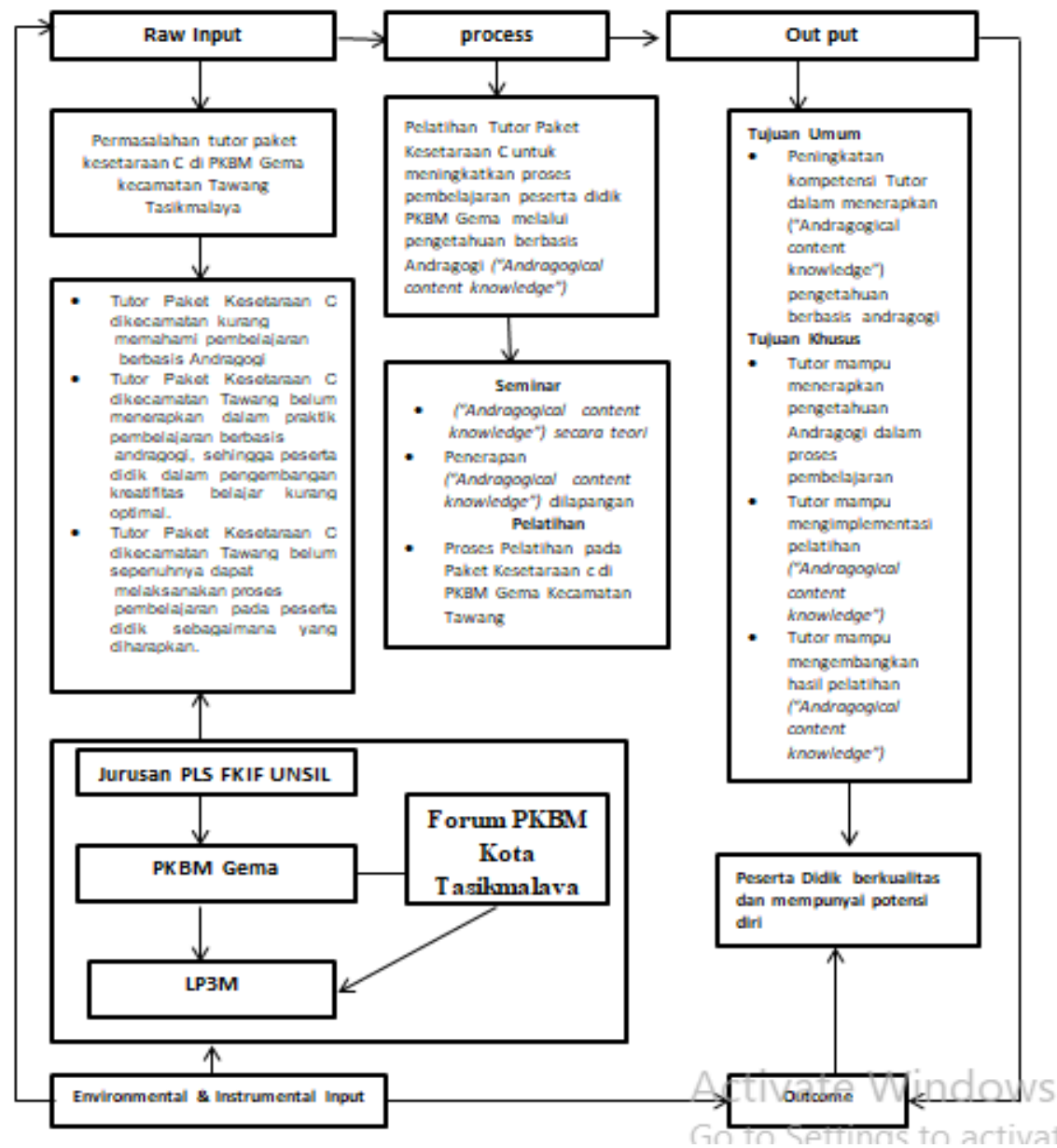

Gambar 1 Model Pelaksanaan Pelatihan ("Andragogical content knowledge") oleh Tutor Kesetaraan paket $\mathrm{C}$ dalam Meningkatkan kompetensi personal proses Pembelajaran pada peserta didik di PKBM Gema Kelurahan Cikalang Kecamatan Tawang Kota Tasikmalaya

Dalam mencapai tujuan pengabdian pada masyarakat melalui Pelatihan “Andragogical content knowledge"oleh Tutor paket Kesetaraan C dalam meningkatkan proses Pembelajaran di PKBM Gema Kelurahan Cikalang Kecamatan Tawang Kota Tasikmalaya. Maka metode yang tepat dalam kegiatan ini adalah pelatihan mengenai konsep "Andragogical content knowledge" (pengetahuan/pembelajaran berbasis andragogi) yang akan dilakukan oleh Tutor Paket Kesetaraan serta praktik penerapan pada pembelajaran. 
Pengabdian ini dilaksanakan bagi tutor Kesetaraan Paket C PKBM Gema Kecamatan Tawang Kecamatan Tasikmalaya. Proses pembelajaran pada pengabdian dilaksanakan dengan menerapkan dua metode yakni penyuluhan dan pelatihan mengenai Penerapan Andragogical Content Knowledge dalam meningkatkan kompetensi personal proses pembelajaran pada peserta didik.

Prosedur kerja dalam mendukung realisasi metode yang ditawarkan adalah:

1. Observasi lapangan dan sosialisasi guna mendata calon peserta (tutor paket keseteraan C) di PKBM Gema kelurahan cikalang kecamatan Tawang Kota Tasikmalaya

2. Membuat dan menyediakan peralatan keterampilan yang dibutuhkan dalam pembelajaran.

3. Mengadakan pelatihan sesuai dengan jadwal yang telah ditentukan bersama.

4. Melaksanakan hasil pelatihan secara sekaligus penilaian .

\section{HASIL DAN PEMBAHASAN}

Kegiatan penyuluhan dan pelatihan ini dilaksanakan dari mulai tanggal 17 Juli sampai 21 Juli 2017. Pada pelaksanaannya, pencapaian kegiatan yang dilaksanakan berada pada tahap penyuluhan mengenai konsep dasar pembelajaran berbasis Andragogi dalam perspektif Pendidikan luar sekolah, Pengembangan Pemahaman mengenai optimalisasi potensi dan Kompetensi Personal pada Proses Pembelajaran Peserta Didik di Pusat Kegiatan Belajar Masyarakat (PKBM) dan overview atau sharing informasi dari mitra bestari dan PKBM Gema yang menyelenggarakan Program Kesetaraan Paket C dalam meningkatkan Kompetensi Personal Proses Pembelajaran.

Materi kegiatan penyuluhan Penerapan Andragogical Content Knowledge adalah sebagai berikut:

1. Konsep dasar metode dalam pembelajaran yang berbasis Andragogi (1x45 menit)

2. Pemehaman mengenai optimalisasi potensi dan kompetensi personal proses pembelajaran pada peserta didik di PKBM (1x45 menit)

3. Konsep dasar proses pemeblajaran berbasis andragogy (1x45 menit)

4. Penerapan pembelajaran berbasis andragogy yang dikembangkan oleh PKBM Gema (1x45 menit) 
Peserta penyuluhan yang menjadi sasaran kegiatan penerapan pembelajaran berbasis Andragogi adalah perwakilan Tutor Dari Setiap Kesetaran paket c di Kecamatan Tawang Kota Tasikmalaya sebanyak 40 orang.

Sarana dan Prasarana yang diperlukan dalam kegiatan ini adalah sebagai berikut Notebook, in focus, kertas HVS, Spidol warna, kursi sebanyak 40 kursi.

Kegiatan penyuluhan dilaksanakan pada pukul 08.00 - 12.00 WIB di PKBM Gema Cikalang Kota Tasikmalaya.

Pelaksanaan pengabdian sesi kedua merupakan tindak lanjut dari penyuluhan yakni pelatihan dan pendampingan sebagai pendalaman materi dan praktikum melalui pelatihan penerapan Andragogical Content Knowledge dalam meningkatkan kompetensi personal proses pembelajaran pada peserta didik PKBM Gema. Materi yang diberikan pada sesi kedua ini yaitu:

1. Pengembangan rencana pembelajaran dan pengembangan materi (1x120 menit).

2. Pengembangan pemahaman mengenai optimalisasi potensi dan kompetensi personal proses pembelajaran pada peserta didik (1x120 menit).

3. Pendampingan yaitu pembuatan rencana pembelajaran dan pengembangan materi (2x180 menit).

\section{E. KESIMPULAN}

Berdasarkan pada hasil kegiatan pengabdian yang dilakukan dapat disimpulkan bahwa Pelatihan Andragogical Content Knowledge bagi tutor kesetaraan Paket C dalam meningkatkan kompetensi personal pembelajaran pada peserta didik di PKBM Gema ini merupakan perpaduan ideal dalam mengatasi permasalahan dan pengembangan para peserta didik Kesetaraan Paket C. tutor dapat mengpalikasikan proses kegiatan belajar mengajar dengan prinsip belajar orang dewasa atau andragogy sehingga peserta didik dapat mengorganisir pengalaman hidupnya dari hasil kegiatan belajar mengajar. Melalui penerapan pelatihan ini memberi peluang kepada peserta didik untuk memberi peluang munculya potensi-potensinya.

\section{F. DAFTAR PUSTAKA}

Hiryanto. (2011). Kemitraan Pusat Kegiatan Belajar Masyarakat (PKBM) dalam upaya mencapai mutu Penyelenggaraan Program Pendidikan non Formal. 
Kamil, Mustofa, (2001), Model Pembelajaran Magang Bagi Peningkatan Kemandirian, Bandung, PPS, UPI.

Knowles, M., (1950). Informal Adult Education: A Guide For Administrator, Leaderand Teachers. New York. Association Press.

Marzuki saleh,(2012). Pendidikan Non Formal (Dimensi dalam keaksaraan Fungsional, Pelatihan, dan Andragogi . Bandung: Rosda

\section{Undang -Undang}

UU Pasal 26 Ayat (2) No. 20 Tahun 2003 Tentang SISDIKNAS 